\title{
Development of Entrepreneurship-Based School Management Models
}

\author{
Tomy Satria Jatmika ${ }^{1}$, Su'ad $^{2}$, Achmad Hilal Madjdi ${ }^{3}$ \\ \{tomysatriajatmika@gmail.com¹, suadfadlan@gmail.com², achmad.hilal@umk.ac.id ${ }^{3}$ \} \\ 1,2,3Basic Education Study Program, Faculty of Teacher Training and Education, \\ Universitas Muria Kudus, Indonesia
}

\begin{abstract}
The government has made various Efforts in order to improve the quality of education. But in reality, produced from Reviews These education graduates are still focused on the hard skills and lack of attention to soft skills. The implementation of SBM as a form of policy that Gives full authority to manage schools has not run optimally in developing soft skills. As an alternative to Overcome this problem, a development research was conducted. The purpose of this study is to develop an entrepreneurshipbased school management models. Preliminary research was conducted using a qualitative approach to gather information Relating to the implementation of SBM in schools. Based on the results of the preliminary research, an entrepreneurial-based school management models was developed. The models was developed following the 4 components of management items, namely planning, organizing, implementing, and monitoring that all education stakeholders Involved. Furthermore, the models was validated by education practitioners and brought to focus group discussions. From the results of expert validation and FGD Obtained an entrepreneurship-based school management models as an alternative in improving the quality of education, especially in terms of developing the soft skills of students.
\end{abstract}

Keywords: entrepreneurship, school management, education

\section{INTRODUCTION}

The purpose of National Education states that education is not only related to the hard skills related to academic achievement, but also related to the soft skills that is associated with the attitude, temperament, character and morals as a citizen. This is in accordance with Act No. 20 of 2003 on National Education System Article 3, which states that the national education serves to develop the ability and character development and civilization of the nation's dignity in the context of the intellectual life of the nation, aims to develop students' potentials to become a man of faith and fear of God Almighty, noble, healthy, knowledgeable, skilled, creative, independent, and become citizens of a democratic and responsible (Depdiknas, 2003).

This is similar to the results of research from Harvard University, United States (US), which reveals that a person's success is not determined solely by the knowledge and technical skills (hard skills), but by the skill to manage themselves and others (soft skills). This study reveals the success is determined only by about $20 \%$ with the hard skills and the remaining $80 \%$ with the soft skills. 
Skills Soft skills more to the psychological, so the impact is not visible directly, but can be felt and seen. Corruptor is one example of the high ability of hard skills related to academic achievement, but very low on soft skills skills. Besides social problems such as unemployment graduated from high school / vocational school or even college graduates into low skills evidence of soft skills possessed citizens. It became a national concern that must be resolved.

Utomo (2010:96) in his research suggests that education who are less able to develop soft skills will produce graduates who are just good at memorizing subjects but little in skill. When already in employment, they will be the engine for the mastery of skills but weak in the lead. Noting this, education can actually be one of the spearheads to reduce the problems that occur.

Various government policies have been made to improve the quality of education both in skills hard skills and soft skills. Actual curriculum that took effect in 2013 already requires teachers to develop soft skills with their load, the assessment of learners. However, in practice it is not easy, teachers should not only assess the behavior of learners, but more than that the teacher should be able to grow and develop soft skills of learners. It is not easy because to develop the potential of hard skills and soft skills not only be the task of a teacher, but required the participation of the various stakeholders of education. Therefore, it takes a good school management to achieve these objectives.

According Budiwibowo (2018:3) management is the process to achieve the goals by planning, organizing, directing, coordinating, monitoring and evaluating. In connection with the school management, the government has given freedom to the schools to organize and carry out various policies with their School Based Management (SBM).

MBS is a new paradigm of education provide broadly autonomy at the school level within the framework of the national education policy. The existence of these MBS is an alternative policy to improve the quality of education and achieving educational goals. By implementing MBS principals are given the freedom and authority to manage the school. It is an alternative to developing a school management with the aim of improving the quality of education in developing the skills of hard skills and soft skills skills. One alternative that can be done is to develop MBS into Entrepreneurship based school management.

The selected alternative for entrepreneurship in Indonesia still lack adequate attention, either by education or society. Many educators are paying less attention to the growth of an entrepreneurial character and behavior of learners, both in vocational schools, as well as in professional education. Their orientation, generally only in preparing the workforce. For that, they need a good school management in order to turn people into human beings who have the character and behavior of entrepreneurs.

Based on the above background, the authors conducted a study of school management development is to develop School Based Enterprise Management.

\section{METHODOLOGY}

This study was designed using a "research and development" or a "research and development". Which in this study, there are two activities, namely research, then from the results of these studies were developed in order to improve the program, a model or a product that already exists.

used in this study measures the development presented by Borg and Gall and developed by Sugiyono by level of study. In addition to following the development model presented by Borg and Gall, this research also see the level of difficulty of research contained in the book Penenlitian Method Development by Sugiyono. In detail the development of research difficulty level is described as follows: (1) Research and development at level 1 (the lowest 
level) is a researcher conducting research to produce a draft, but did not proceed with making the product and testing it; (2) Research and development on level 2, is the researchers did not conduct research, but direct testing of existing products; (3) Research and development at Level 3, is a researcher conducting research to develop products that already exist, create a product and test the efficacy of the product; (4) Research and development at level 4, is a researcher conducting research to create new prouk make the product and test the effectiveness of these products (Sugiyono, 2019: 42).

The data in this study were obtained at this stage and Research to find potential problems that will be used for product planning materials. The data used in the form of qualitative data in the form of interviews, observation, and the results of the documentation that comes from informants. Informants were used as the source of which is the principal, teachers, students, and parents or community leaders as the executor of interest in the implementation of schoolbased management.

Data collection activities carried out at the stage of determining the potential and problems, gathering information and literature, as well as at the time of product validation. The technique used in this study using triangulation techniques on data obtained through structured interviews, structured observation, and documentation.

\section{1) Observation structured}

According Sugiyono (2019: 215) structured observations are designed to systematically observation of what is observed, when and where it is.

\section{2) Structured interviews}

Structured interviews typically involves the act of giving questions to the informant with the same question.

\section{3) Documentation}

Engineering documentation is done by collecting photographs and documents required and supporting research.

Data analysis technique used is a qualitative analysis is inductive, ie divulging the analysis based on the data obtained, subsequently developed into a hypothesis, and then look for repetitive data to verify the hypothesis (Sugiyono, 2019: 368).

Steps being taken in the data analysis by Miles and Huberman in Sugiyono (2019: 369) is as follows:

1) Data reduction

Summarizes and focuses on the data studied.

2) presentation of Data

Presentation of data is done with descriptive tables and charts.

3) conclusion

The conclusion is a finding that such a description or picture of the object under study.

\section{RESULT AND DISCUSSION}

Based on the initial research that has been conducted shows that MBS has been implemented in all schools, but its implementation is still not optimal. In the management of planning and organizing is not clearly available to the planning and organizing yangberkaitan 
softskill development of learners or it can be said that there is no school that clearly planned development of entrepreneurship among students. On the other hand there are schools that have implemented pengitegrasian the entrepreneurial development of soft skills of learners with a variety of entrepreneurial activity of children, but who do not yet conceptualized activities clearly. Yet from these activities bring many great benefits in improving soft skills and hard skills of learners.

Based on the existence of an entrepreneurial-based school management. This management model can be used as a reference for the organizers of the school in order to optimize all the potential schools to be more productive, especially in terms of soft skills development of learners based entrepreneurship.

\section{CONCLUSSION}

MBS is an alternative policy to improve the quality of education and achieving educational goals. By implementing MBS principals are given the freedom and authority to manage the school. It is an alternative to developing a school management with the aim of improving the quality of education in developing the skills of hard skills and soft skills skills. One alternative that can be done is to develop MBS into Entrepreneurship based school management.

The selected alternative for entrepreneurship in Indonesia still lack adequate attention, either by education or society. Many educators are paying less attention to the growth of an entrepreneurial character and behavior of learners, both in vocational schools, as well as in professional education. Their orientation, generally only in preparing the workforce. For that, they need a good school management in order to turn people into human beings who have the character and behavior of entrepreneurs.

\section{REFERENCES}

[1] Arikunto, Suharsimi dkk. 2008. Manajemen Pendidikan. Yogyakarta: Aditya Media

[2] Budiwibowo, Satrijo. 2018. Manajemen Pendidikan. Yogyakarta : Penerbit Andi.

[3] Departemen Pendidikan dan Kebudayaan. 2003. Kamus Besar Bahasa Indonesia Edisi Kedua.

Jakarta : Balai Pustaka

[4] Haryati, Sri. 2012. Research and Development sebagai salah satu model penelitian dalam bidang pendidikan”. Vol 37 No 115 September 2012.

[5] Kementerian Pendidikan Dan Kebudayaan. 2013. Panduan Pembinaan Manajemen Berbasis Sekolah di Sekolah Dasar. Jakarta : Kemendikbud

[6] Majid,Abdul. 2005. Perencanaan Pembelajaran. Bandung: Remaja Rosdakarya.

[7] Manab, Abdul. 2015. Manajemen Kurikulum : Pembelajaran di Madrasah. Yogyakarta : Kalimedia

[8] Mulyani, Endang. 2010. Pengembangan Pendidikan Kewirausahaan. Jakarta: Balitbang

[9] Mulyani, Endang. 2011. Model Pendidikan Kewirausahaan di Pendidikan DasaR dan Menengah. Jurnal Ekonomi dan Pendidikan. Volume 8(1)

[10] Mulyasa. 2017. Manajemen Berbasis Sekolah( Konsep, Strategi, dan Implementasi). Bandung : Remaja Rosdakarya.

[11] Mustiningsih. 2016. Konsep Dasar dan Komponen MBS di Sekolah Dasar. Makalah. Dalam : Bimtek Manajemen Bersbasis Sekolah, Februari 2016. 
[12] Pidarta, Made. 2004. Manajemen Pendidikan Indonesia. Jakarta : PT Rineka Cipta

[13] Sekretariat Negara RI. 2003. Undang - Undang Nomor 20 Tahun 2003 Tentang Sistem Pendidikan Nasional. Jakarta: Sekretariat Negara RI.

[14] Sugiyono. 2019. Metode Penelitian \& Pengembangan. Bandung: Alfabeta

[15] Suparman, Atwi. 2014. Desain Instruksional. Jakarta: PAU-PPAI Universitas Terbuka

[16] Setyosari, Punaji. 2012. Metode Penelitian Pendidikan dan Pengembangan Edisi ke Empat. Jakarta: Prenadamedia Group 